\title{
Youtube as Da'wah Media Innovation in Disruption Era
}

\author{
Mustofa Hilmi \\ Universitas Islam Negeri Walisongo Semarang \\ mustofa.hilmi@walisongo.ac.id
}

Received: Feb 09, 2020 | Revised: Jan 22, 2021 | Approved: Feb 13, 2021

\begin{abstract}
This article aims to analyze YouTube as a da'wah media for Muslim preachers in the disruption era. The use of Youtube as a medium of preaching significantly impacted developing increasingly competitive digital da'wah content. The digitalization of Islamic da'wah on Youtube has made the Dai (preacher) more proactive in making updates and adjustments. Dai's proficiency in the mastery of dakwah media via Youtube is one of the determining factors in digitizing da'wah. Therefore, Dai, who uses Youtube as a medium of preaching in the digital era, must always carry out innovation. Dai can create material videos by adding stimulating effects such as animated visualization, adding unique descriptions for important material points, and religious music back sounds. Dai also take advantage of image editing applications such as CorelDRAW, Photoshop, and video applications such as Filmora, VideoPad, or Adobe Premiere in the material creation process. Innovation is the process of making a da'wah video is very important so that the da'wah material can touch the community, especially the millennial generation.
\end{abstract}

Keywords: Youtube, Innovation, Media, Disruption

Abstrak: Artikel ini bertujuan untuk menganalisis penggunaan media Youtube sebagai media dakwah para penceramah muslim di era disrupsi. Penggunaan Youtube sebagai media dakwah telah memberikan dampak siginifikan dalam pengembangan konten dakwah digital yang semakin kompetitif. Hadirnya digitalisasi dakwah Islam di Youtube menjadikan Dai (penceramah) semakin proaktif dalam melakukan pembaharuan dan penyesuaian. Kecakapan Dai dalam penguasaan media dakwah melalui Youtube menjadi salah satu faktor penentu dalam keberhasilan digitalisasi dakwah. Maka, inovasi harus selalu dihadirkan oleh para Dai yang menggunakan Youtube sebagai media dakwah di era digital. Dai dapat melakukan inovasi dalam pembuatan video materi dengan menambah efek yang menarik seperti visualisasi animasi, penambahan deskripsi khusus untuk poin penting materi, dan backsound musik religi. Dai juga dapat memanfaatkan aplikasi editing gambar seperti CorelDRAW dan Photoshop serta aplikasi video seperti Filmora, VideoPad, atau Adobe Primiere dalam proses pembuatan materi. Inovasi dalam proses pembuatan sebuah video dakwah sangat penting dilakukan agar materi dakwah dapat menyentuh masyarakat khususnya para generasi milenial.

Kata Kunci : Youtube, Inovasi, Media, Disrupsi

\section{Introduction}

In facing the current disruption era, the world is faced with rapidly evolving information and changing fundamentally and primarily in every life principle. As someone who organizes da'wah activities, dai should respond quickly and intelligently 
to the progress. People have interests that changing over time. Of course, Dai could not stop this tendency, so that Dai must make adjustments. Dai must try to maintain da'wah so as not to be left behind and out of date. The use of information technology tools as a medium for distributing information to the public is the right step that must be taken.

The use of media in the industrial era 4.0 is a necessity. The da'wah process is not only enough to be organized with traditional media such as teaching at mosques, musholla, and majelis taklim from house to house. The data explained by HootSuite shows that internet users in Indonesia are 175.4 million of 272.1 million population (https://datareportal.com/reports/digital-2020-indonesia). Moreover, in Covid-19, the number of internet users until the second quarter of 2020 increased to 196.7 million (https://money.kompas.com/read/2020/11/09/213534626/). This fact illustrates that more than half of Indonesia's people spend their time doing online activities than offline. This reality confirms that the use of $d a^{\prime}$ wah media must follow the times so that the messages can be received by Mad'u (Marwantika, 2019). Among the media that has a significant influence is Youtube. Hootsuite's survey shows that the most widely social media used by Indonesians is Youtube, 88\%. The second and third positions were occupied by WhatsApp 83\% and Facebook 81\%. (datareportal.com/reports/digital2019-indonesia).

As a new media, Youtube can display audio and visual messages and give a free service where the audience can interact by watching, uploading, downloading, and commenting on the content. The audience has extensive access. No one can stop internet exposure. Youtube offers decentralized ownership so that the user acts as the social media owner (Simarmata, 2014). These media provide various videos with different segment variants that various users around the world have uploaded. Besides it, the audience can build a network through channels made according to their chosen segment. The number of subscribers marks the network. New media is a medium that offers digitization, convergence, interactivity, and development of the network in the process of message creation and dissemination (Flew, 2002). Users can choose information provided while controlling the result of output. This concept of the interactive aspect is the center of understanding new media. In the transformation era, da'wah is impossible to develop only by using traditional media with all limitations. Because essentially, da'wah must adapt to the dynamics of the times (Rohmatulloh, 
2018). This article is looking for the role of Youtube as a media for da'wah in the disruption era. The Dai must use Youtube for the benefit of preaching Islam.

\section{Method}

This article is a study using the library research and descriptive qualitative approach. The author will explore data from various sources to describe Youtube as a medium for da'wah innovation in the disruption era. The data is taken from journals, books, and research related to the development of Youtube and da'wah media. in analysis of data, the authors used three stages. There are data reduction, data presentation, and make conclusion or verification (Sugiono, 2008). The first stage is data will be reduced by sorting and selecting raw data that has been obtained from extracting data sources. Then the author will take a selection through descriptions and summaries. Data will be classified into specific categories. The second stage is to provide the data by compiling it into descriptive information. The concepts will be implemented quickly. The third stage is to make a conclusion or verification based on evidence of research.

\section{Result and Discussion}

\section{Innovation and Media of Da'wah}

In da'wah's study, the media etymologically comes from the Arabic language, namely wasilah, to achieve the desired goal (Al-Bayanuni, 2001). Ibn Mandzur argues that the word is a plural form of the al-wasalu, and al-wasailu means the throne of a king, friend, or close (Ibn Mandzur, 2005). In terminology, da'wah's media is a medium used to connect ideas and concepts in Islamic teachings to mad'u. The existence media of da'wah is very urgent in the process of developing the spread of Islam. The ability to use the media of da'wah is adapted to times. Al-Quran has explained in Surat Al-Maidah (5) verse 35. In Tafsir Jalalain, it is explained that the meaning of al-wasilah is (medium that can bring yourself to Him by obedient). It can be understood that Allah SWT ordered muslims to use wasilah to be classified in muflihun.

In terms of da'wah, al-wasilah is defined as a media of da'wah. Media are tools used to send messages such as books, television, film, video, and internet (Amin, 2009). The media are neutral. Depending on the communicator, the media can serve to deliver both positive and damaging messages. It is different from the media of da'wah; the 
emphasis is on how big the media can get closer to Allah SWT. Media of da'wah must have a positive value that must be projected as a tool for Islam's spread. Dai must design media of da'wah as a tool to bring mad'u closer to Allah SWT. The form of wasilah or media always develops according to current development. As it is now, the media has evolved into a large industry that has a broad influence on society (Setyawan, 2020).

Da'wah media can facilitate the achievement of da'wah missions. (Latief, 2012). For example, Dai can use television to convey the contents of the verses of Al-Quran by providing explanations through verbal and nonverbal communication. It can make mad'u quickly receive messages. Dai also can give a detailed explanation of a problem by writing in media. The articles can be written in several forms such as newspapers, magazines, or books so that mad'u can easily make documentation. There is also a radio that functions as an audio medium for mad'u who wants an explanation from the listener's senses. The development of the media has reached a great level after the discovery of new media. The new media provides various kinds of content that are easily accessible by mad'u. By having a smartphone that is connected to the internet, mad'u can access information of da'wah. In response, Dai must be an innovative person to deliver messages to mad'u. Da'wah messages are delivered using online media with kind innovations that can attract the attention of an audience.

Etymologically, innovation means renewal and change. Innovaation has a verb form, innovo. It is meant to update and to change. Innovation is the work of planned human thought to new changes or towards improvement (Idris, 1992). Innovation must have good value for the user. The more individuals feel helped by the work that someone has created, the more innovation can be considered successful. Rogers defines the introduction and application of new ideas, processes, products and procedures to units that implement to give individuals profit, groups, organizations and society. He also defines innovation as a service product, process, new way, and policy conducted through a logical process. He explains that "an idea, practice, or object perceived as new by the individual or other unit disruption" (Rogers, 1983). Through the definition of innovation, Dai needs to study the use of media in da'wah. Dai must try to create good ideas that can be beneficial to mad'u. Developments in the mastery of media can make mad'u like have something new in the process of da'wah.

Facing the world change, dai must be an active individual. The existence of da'wah is not enough with "wait and see". Making decisions by waiting for complete data 
is too slow. Deciding after the problem happened to mad'u and comfortable in the old da'wah system are mistakes. Like a leader, Dai must move on from the old da'wah system to the second stage of thought, "see and do." Dai must respond by innovating in the da'wah process. It is an absolute necessity that cannot be avoided (Prihanisetyo, 2018).

\section{Disruption Era}

Etymologically, disruption means to disturb or interruption. This word is often interpreted as an effort to change the already established order. The industrial revolution means changes quickly that can change the established rules of life. Related to this, Christensen has identified that two types of innovation can influence organization or business continuation. There are sustaining and disrupting. Sustaining means continuous innovation. This is related to the improvement of an existing system. Meanwhile, disrupting means destructive innovation. It tends to open new markets by lowering prices or designing different products (Rahmawati, 2018).

The disruption era is a challenge in various fields of life, especially the economy field. Not a few multinational companies are bankrupt. Now, big brands like Siemens and Nokia are just a story. Post offices and transportation also have to experience rapid development. Various new virtual companies that more efficient and low cost has succeeded in changing the old established models. Also, in the da'wah field, the first change that is occurring is on demand. The emergence of various da'wah forms such as writing on websites, infographics, podcasts, and Youtube displays video and audio simultaneously. Mad'u can choose the da'wah model according to themselves. Not only watching, but mad'u can also save and download the content that they see. Mad'u will eventually experience more personalized learning. The second is open source. Digital da'wah content offers an unlimited variety of free content. Mad'u can follow and get knowledge intensively. In contrast to da'wah offline, where mad'u do not have to think about time, place, and cost (Kasali, 2017). To maintain existence, everyone must do innovate. Dai must not be apathetic to the demands of change. Da'wah must be developed that oriented towards increasing intelligence, spirituality, and achievement of mad'u. The ignorance of the disruption era can make stagnant of da'wah that mad'u would eventually leave it. 
Da'wah must transform and modify to good form to compete in the strategy of survival in the future. There are six changes (Kasali, 2017) that are occurring now. The first is technology. It has changed all products to digital. It cannot be denied that the da'wah process must also do the same thing. That is digitization. Old methods such as da'wah conventional by opening teaching in mushola, mosque, or majlis taklim need to be reformulated. It is must be processed to digital. Starting from the place, the material, until how to communicate between dai and $\operatorname{mad}^{\prime} u$.

Second, the millennial generation is the central core in the disruption era. This group is characterized by fluent technology, intense socialize using social media, expressiveness, tolerance of cultural differences, caring about the environment, and quickly changing from one thought or job to another. The millennial generation has a high dependence on technology because most of their lives are integrated with it. The millennial generation is mad'u today. They can easily access da'wah teachings as actively conveyed by dai through technology media (Miftahuddin, 2018; Nugraha et al., 2020). Smartphones have a more important role in reading media than printing media. Every mad'u has a social media account as an identity and a medium of information in cyberspace. They will increasingly leave electronic media such as television and radio because online media has more advantages than previous technologies. Therefore, dai must be able to increase the use of digital media and technology. Dai must revitalize da'wah's method as a step to attract mad'u's attention to achieve success in da'wah (Santoso, 2019).

Third, the speed of the microprocessor which developing in 24 months. It is implicated in the demands of humans to be able to think and act quickly. Everyone can do anything without depending on time and place. An individual's response now determines his existence in the future. The fourth is the emergence of a disruptive leader. It is someone with full awareness of creating breakthroughs and creating the da'wah model through new methods. It can create various kinds of da'wah innovations by utilizing technology, such as the social media meme account "Garis Lucu" (Rohmatulloh, 2019). The fifth is the emergence of changes in how to achieve goals. Humans have now developed a disruptive business model that quickly reaches goods and services, accessible, simple, and populist. The sixth is the internet of things. It is the development pattern of the digital world that has united all humans. So there is no local 
or regional citizenship, but the existence is world citizenship. Individual consciousness requires the concept of Mondial mindset, global thinkers, and universal perspective.

\section{Youtube as Media of Da'wah}

The key to Dai's success in facing the industrial era 4.0 is creating information and communication technology innovations integrated with da'wah. This step can make Mad'u effectively receive da'wah messages without depending on place and time. The audience can access da'wah messages wherever they are. Besides, they can choose da'wah form according to themselves by selecting materials. They can choose a material that available and attractive in the media.

Communication with digital media generally has more advantages than traditional media. Digital media can provide a more interactive exchange of information. The public can make feedback such as suggestions, recommendations, or criticism in real-time. This feedback can also be received directly by the dai without delay. So that dai can immediately follow up on it. One of the most influential of digital media today is Youtube. This channel has the highest number of users than other media. The survey shows that the Indonesian population who actively accesses social media reaches 150 million people. Youtube is the most widely used online media. Nielsen's data shows that Youtube is a platform that has the largest market share in Indonesia. It is a $68 \%$ percentage of viewing television shows or films (Nielsen.com, 2020). Likewise, a survey by Asosiasi Penyeleggara Jasa Internet Indonesia (APJII) in 2019-2020 (Q2) stated that $61 \%$ public often access Youtube. This indicates that Youtube is a prevalent medium. It is appropriate for use as a medium for da'wah.

This channel has different from previous electronic media such as television and radio. Both mass media have broadcast schedules that the station producer has determined. The public does not have the freedom to choose programs; they have to adjust the production house's schedule. Especially advertisements that always appear with a long duration in the program. Unlike Youtube, the audience has flexibility and convenience in viewing or determining programs. Audiences can access Youtube anywhere because it is installed by default on smartphones. Youtube has more optional choices than electronic media before. Likewise, with a few ads. The advertisement duration is only a few seconds that can be skipped. Through this online media, the video material presented by dai can last longer on the website. This platform also has various 
features that are not available on television or radio-like pause, video quality, speed, and playlists, unlike traditional media. Mad'u can forget it quickly because of the limitations of the brain in memorizing. There is no access to playback the material that has been delivered. The audience can access content as long as connected to the internet.

In the previous decade, da'wah carried out by dai still limited method. It uses offline teaching lectures and Tabligh Akbar, such as mosques, mushala, or certain meeting places. The audience must follow the da'wah according to the time and place that has been determined. This method must be changed. Da'wah needs to adjust the conditions of mad'u. Dai must take advantage of online media in da'wah. The use of Youtube as media for da'wah is the right step. Dai can make innovations in the video. The material can be delivered by adding stimulating effects such as animation, additional information, and background, such as content about prostration procedures in prayer. Dai can show detail every movement, such as seven parts of the body that must be attached, the correct position of the hands or feet, and the readings in every movement.

Dai can use editing applications such as CorelDRAW, Photoshop, Filmora, VideoPad, or Adobe Premiere in the creation process. In the manufacturing process, dai is required to make the best innovation by using an editing application: the more expert Dai using it, the more interesting the content to be followed. Dai must be able to dialogue actively with a digital culture so that Islamic da'wah can be spread well in online media (Ritonga, 2019).

Youtube has characteristics that can be used by Dai or preacher as a medium of da'wah. Some are :

1. Youtube has a video duration that can be adjusted to Dai. Dai can make the content duration as needed. This is different from television and radio platforms which have limited duration. The duration of that media has determined by the producer. This is different from Youtube; dai can learn $\operatorname{mad}^{\prime} u$ habits by watching videos. Videos with a too-long duration can make someone boring.

2. On the other hand, video duration that too short cannot contain enough information. With these advantages, dai can determine the content to be delivered by considering it. Content should be adjusted according to the viewer segment so that the material can be received quickly. 
3. Youtube has a security system. Every uploaded video will be verified, such as content, categorization of children or adults, copyright, and several other confirmation questions.

4. Youtube offers a fee for every uploaded video. There are requirements to get it. This feature is monetization. Channels that are made at least two years old, original, and have 1,000 viewers. With this feature, dai does not need to think about the cost of making a video. Youtube provides rewards for the video that has been produced. However, Dai should maintain his intention to da'wah. Da'wah is the call of God. It is not to make income in da'wah. The sincerity of intention is essential so that Dai is not trapped in da'wah's commodification (Wardani, 2018).

5. Youtube can be enjoyed offline. This feature allows mad'u to access it anytime without connecting to the internet. However, to enjoy this menu, mad'u must first download the video. There is a simple editor feature at the start of the process before uploading. These features include video cutting, color filters, or adding the effect of moving each scene to video.

\section{Conclusion}

Islamic da'wah is required to be responsive in changing times. The success of da'wah can be achieved by optimizing the use of media. Insisting on the old ways and methods only makes stagnant of da'wah process. In terms of using youtube, Dai is required to technical mastery skills and video making. Dai can take advantage of image editing applications such as CorelDRAW and Photoshop. Dai also can use video applications such as Filmora, Videopad, or Adobe Premiere in the creation process. Innovation is the process of making a video of da'wah is significant. Dai can keep in

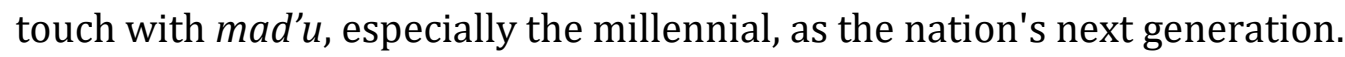

\section{References}

Al-Bayanuni, Muhammad Abdul Fatah, (2001). al-Madkhal ila 'ilmi al-Da'wah, Beirut : Risalah Publisher

Biagi, Shirley, (2010). Media/Impact : Pengantar Media Massa, Jakarta : Salemba Humanika

Flew, Terry, (2002). New Media: An Introduction. New York: Oxford University Press 
Ibn Mandzur, (2005). Abi al-Fadzil Jamaluddi Muhammad ibn Makrm, Lisan al-'Arab li Ibn Mandzur, Beirut : Dar Sader Publisher

Idris, Lisma Jamal, (1992). Pengantar Pendidikan, Jakarta : Grasindo

Kasali, Renald, (2017). Disruption. Jakarta : Gramedia Pustaka Utama

LATIEF, Hilman. ISLAMIC CHARITIES AND DAKWAH MOVEMENTS IN A MUSLIM MINORITY ISLAND: The Experience of Niasan Muslims. JOURNAL OF INDONESIAN ISLAM, [S.l.], v. 6, n. 2, p. 221-244, dec. 2012. ISSN 2355-6994. Available at: <http://jiis.uinsby.ac.id/index.php/JIIs/article/view/106>. Date accessed: 23 Mar. 2021. doi:http://dx.doi.org/10.15642/JIIS.2012.6.2.221-244.

Marwantika, A. (2019). Potret dan Segmentasi Mad'u Dalam Perkembangan Media di Indonesia. Al-Adabiya: Jurnal Kebudayaan Dan Keagamaan, 14(01), 1-14. https://doi.org/10.37680/adabiya.v14i01.100

Miftahuddin, L. (2018). Ulama dan Media Sosial: Analisis Pesan Dakwah KH Mustofa Bisri di Twitter. MUHARRIK: Jurnal Dakwah Dan Sosial, 1(02), 117-135. https://doi.org/10.5281/zenodo.3545537

Nugraha, R., Parhan, M., \& Aghnia, A. (2020). MOTIVASI HIJRAH MILENIAL MUSLIM PERKOTAAN MELALUI DAKWAH DIGITAL. MUHARRIK: Jurnal Dakwah Dan Sosial, 3(02), 175-194. https://doi.org/10.37680/muharrik.v3i02.398

Prihanisetyo, Adi, (2018). Era Disruption Sebuah Tantangan Atau Bencana Sebuah Telaah Literatur, Balikpapan, Jurnal Mebis, 3 (1), 11-20. https://doi.org/10.33005/mebis.v3i1.19

Rogers, Everett M, (1983). Diffusion of Innovation, London, The Free Press

Santoso, Bobby Rachman, (2019). Revitalisasi Metode Dakwah Anarkronistis Dai Generasi Milenial, Mataram: Jurnal Tasamuh, 17 (1), 133-154. https://doi.org/10.20414/tasamuh.v17i1.1350

Simarmata, Salvatore, (2014). Media Baru, Ruang Publik Baru, dan Transformasi Komunikasi Politik di Indonesia, Jakarta: Interact, 3 (2), 18-36. http://dx.doi.org/10.36388\%2Fia.v3i2.721

Sugiyono, (2008), Metode Penelitian Kuantitatif Kualitatif dan R\&D, Bandung : ALFABETA

Rahmawati, Fitri, (2018). Kecenderungan Pergeseran Pendidikan Agama Islam di Indonesia Pada Era Disrupsi, Pamekasan, Jurnal Tadris, 13 (2), 246-255. http://dx.doi.org/10.19105/tjpi.v13i2.1752 
Ritonga, M. (2019). Komunikasi Dakwah Zaman Milenial. Jurnal Komunikasi Islam Dan Kehumasan (JKPI), 3(1), 60-77. Retrieved from http://jurnal.radenfatah.ac.id/index.php/JKPI/article/view/4263

Rohmatulloh, D. (2018). Peta Dinamika Dakwah dalam Mobilitas Muslim Indonesia di Abad ke-20. MUHARRIK: Jurnal Dakwah Dan Sosial, 1(01), 86-96. https://doi.org/10.5281/zenodo.3545043

Rohmatulloh, D. (2019). In Meme Dakwah: A Netnographic Study of Garis Lucu Social Media Accounts. In The 19th Annual International Conference on Islamic Studies (AICIS 2019). Zenodo. doi:10.5281/zenodo.3991863

Setyawan, A. (2020). Dakwah yang Menyelamatkan: Memaknai Ulang Hakikat dan Tujuan Da'wah Islamiyah. Al-Adabiya: Jurnal Kebudayaan Dan Keagamaan, 15(02), 189-199. https://doi.org/10.37680/adabiya.v15i02.487

Wardani, M. (2018). Komodifikasi Citra Perempuan Muslim dalam Dunia Fashion: Analisis Semiotika Tayangan Dua Hijab Trans 7. MUHARRIK: Jurnal Dakwah Dan Sosial, 1(01), 22-46. https://doi.org/10.5281/zenodo.3545035

,Digital 2019: Indonesia. Di akses pada Januari 02, 2020, dari Datareportal.com/reports/digital-2019-indonesia

,Konsumen Digital Menunjukkan Pertumbuhan Tren Positif. Di akses pada Januari, 24, 2021, dari $\underline{\text { https://www.nielsen.com/id/id/press- }}$ releases/2020/konsumen-digital-menunjukkan-pertumbuhan-tren-positif/ 